\title{
Circadian Transcriptomic and Epigenomic Remodeling in Response to Lipid Overload and Human Obesity
}

Laura Sardón Puig ${ }^{1}$, Ali Altıntaş ${ }^{2}$ Salvador Casaní-Galdón ${ }^{3}$, Brendan M. Gabriel ${ }^{4}$, Romain

Barrès $^{2}$, Ana Conesa ${ }^{5}$, Alexander V. Chibalin ${ }^{1}$, Erik Näslund ${ }^{6}$, Anna Krook ${ }^{4}$, Nicolas J. Pillon ${ }^{4}$, Juleen R. Zierath ${ }^{1,2,4^{*}}$

${ }^{1}$ Department of Molecular Medicine and Surgery, Section of Integrative Physiology, Karolinska Institutet, Stockholm, Sweden.

${ }^{2}$ Novo Nordisk Foundation Center for Basic Metabolic Research, University of Copenhagen, Copenhagen, Denmark.

${ }^{3}$ Biobam Bioinformatics S.L, Valencia, Spain

${ }^{4}$ Department of Physiology and Pharmacology, Section of Integrative Physiology, Karolinska

Institutet, Stockholm, Sweden

${ }^{5}$ Department of Microbiology and Cell Science, Institute for Food and Agricultural Sciences, Genetics Institute, University of Florida, Gainesville, Florida, USA

${ }^{6}$ Division of Surgery, Department of Clinical Sciences, Danderyd Hospital, Karolinska Institutet, Stockholm, Sweden.

*Corresponding Author: $\quad$ Professor Juleen R. Zierath Department of Molecular Medicine and Surgery, Section for Integrative Physiology,

Karolinska Institutet, Biomedicum C4 Solnavägen 9 , SE 17177 Stockholm, Sweden

Tel: +46 (0) 8-524 87580

Email: Juleen.Zierath@ki.se 


\section{ABSTRACT}

Aims/hypothesis: Obesity and elevated circulating lipids may impair metabolism by disrupting the molecular circadian clock. We tested the hypothesis that lipid-overload may interact with the circadian clock and alter the rhythmicity of gene expression through epigenetic mechanisms. Methods: We determined the effect of the saturated fatty acid palmitate on circadian transcriptomics and examined the impact on histone H3 lysine K27 acetylation (H3K27ac) and the regulation of circadian rhythms in primary human skeletal muscle myotubes. Total H3 abundance and histone $\mathrm{H} 3 \mathrm{~K} 27 \mathrm{ac}$ was assessed in vastus lateralis muscle biopsies from obese and normal weight men.

Results: Palmitate disrupted transcriptomic rhythmicity in myotubes. Genes that lost or gained rhythmicity after palmitate treatment were involved in metabolic processes, protein translation and transport, and transcriptional regulation. Histone H3K27ac, a marker of active gene enhancers, was modified by palmitate treatment in myotubes, but not in skeletal muscle from men with obesity.

Conclusion/interpretation: Palmitate disrupts transcriptomic rhythmicity and modifies histone H3K27ac in circadian manner, suggesting acute lipid-overload alters the epigenetic state of skeletal muscle. Our results indicate that dietary saturated fatty acids impart post-transcriptional modifications to histone proteins and regulate circadian transcriptomics. 
Keywords: Epigenetics, Histone Modifications, Transcriptional Regulation, Circadian Rhythms, Saturated Fatty Acids, Obesity, Skeletal Muscle

Abbreviations: BMAL1 (also known as aryl hydrocarbon receptor nuclear translocator-like protein [ARNTL]); CIART (Circadian Associated Repressor of Transcription); CLOCK (Circadian Locomotor Output Cycles Kaput); CRY (Cryptochrome); DBP (D site of albumin promoter (albumin D-box) binding protein); H3K27ac (Histone H3 Lysine K27 acetylation) HPRT (hypoxanthine guanine phosphoribosyl transferase); NR1D1 (Nuclear Receptor Subfamily 1 Group D Member 1, also known as REVERBa); NR1D2 (Nuclear Receptor Subfamily 1 Group D Member 2, also known as REVERBß); PER (Period); TBP (TATA box binding protein), TEAD1 (Transcriptional enhancer factor TEF-1, 18S (18S ribosomal RNA). 


\section{INTRODUCTION}

Obesity is characterized by an increased level of circulating fatty acids and ectopic lipid accumulation in peripheral tissues (1). The pathological storage of lipids in skeletal muscle can lead to metabolic disturbances and insulin resistance (1). Obesity is also tightly linked to disrupted circadian rhythms $-24 \mathrm{~h}$ cycles that allow organisms to anticipate diurnal changes in physiology and behavior (2-5). Circadian misalignment increases circulating levels of glucose, free fatty acids and triglycerides (6), as well as adversely affecting leptin and ghrelin levels (7), which can have deleterious effects on glucose and energy homeostasis (8).

Disruption of the circadian clock by sleep deprivation or shift-work increases the risk of cardiometabolic diseases, including type 2 diabetes and obesity (9-11). Simulated chronic jetlag in mouse models leads to leptin resistance and obesity (12), indicating that circadian disruption directly contributes to the development of metabolic disease. Circadian clock mutant mice are hyperphagic and develop obesity, with hyperlipidemia, hyperglycemia and hyperinsulinemia and systemic alterations in glucose homeostasis (13). Dietary interventions can also lead to circadian disruption, with long-term high fat diets altering the core clock machinery and clock-controlled genes in liver and kidney of mouse models (2). Clinically, the relationship between circadian biology and metabolism is relevant since men and women with obesity present altered mRNA expression of core clock genes in skeletal muscle, blood cells and visceral adipose tissue (3-5). Collectively, these results provide evidence to suggest crosstalk between metabolic health, nutritional status, and circadian rhythms.

Circadian rhythms are controlled by transcriptional regulation and post-translational modifications $(8 ; 14)$. The core clock is composed of cell-autonomous transcription-translation feedback loop, comprised of a CLOCK:BMAL1 heterodimer that transcribes feedback repressors PER, CRY, DBP and NR1D1 (8; 14). The mechanisms by which the CLOCK:BMAL1 heterodimer regulates the core clock machinery are established (14), however 
the mechanisms by which the core clock regulates transcription and post-transcription modifications of clock-controlled genes remains an evolving area of investigation $(8 ; 15)$. The CLOCK:BMAL1 heterodimer binds to DNA, which enables chromatin remodeling and activation of transcription $(16 ; 17)$. This heterodimer can also modulate the activity of histone acetyltransferases and histone deacetylases, with BMAL1 and CLOCK acting as histone acetyltransferases and NR1D1 and BMAL1 acting as transcription factors $(8 ; 16-19)$. Circadian transcription is synergistically regulated by different environmental factors, including energetic states, levels of metabolites, and fuel substrates, through epigenomic modifications, including histone modifications $(8 ; 20)$. For example, calorie restriction is associated with an induction of amplitude of clock genes and accumulation of histone acetylation (H3K9/K14 and H3K27) at circadian hepatic promoters (19). Thus, environmental factors interact with the core clock machinery to influence circadian rhythms and gene expression through epigenetic processes.

Core clock gene expression is altered in skeletal muscle from men and women with obesity (3). Moreover, changes in clock gene expression were correlated with circulating fatty acid levels and altered by palmitate exposure in primary human muscle cells (3). Here we tested the hypothesis that saturated fatty acids may directly interact with the circadian clock and alter the rhythmicity of gene expression in skeletal muscle. We further tested whether palmitate exerts effects on rhythmicity of gene expression through epigenetic mechanisms. To address this, we determined the effect of the saturated fatty acid palmitate on skeletal muscle circadian transcriptomics and examined the impact on histone $\mathrm{H} 3$ lysine K27 acetylation (H3K27ac) and the regulation of circadian rhythms in skeletal muscle. 


\section{METHODS}

\section{Subjects}

Vastus lateralis muscle biopsies were obtained from 7 healthy men to establish primary skeletal muscle cell cultures to determine the effects of palmitate on circadian transcriptomics, histone $\mathrm{H} 3$ protein abundance, and $\mathrm{H} 3 \mathrm{~K} 27 \mathrm{ac}$. Vastus lateralis muscle biopsies were obtained from a cohort of men with normal weight $(n=6)$ or obesity $(n=6)$ as described earlier $(3 ; 21)$ for immunoblot analysis of $\mathrm{H} 3$ protein abundance and H3K27ac. Clinical characteristics of the men with normal weight or obesity are presented in Table 1 . Studies were approved by the regional ethics committee of Stockholm and conducted in accordance with the Declaration of Helsinki (2012/1955-31/1, 2013/647-31/3, 2012/1047-31/2 and 2016/355-31/4). Participants gave informed consent prior to enrolment.

\section{Primary human skeletal muscle cell cultures}

Primary myoblasts were grown in DMEM/F12+Glutamax with 16\% FBS and 1\% AntibioticAntimycotic (100X). Cells were regularly tested for mycoplasma contamination by PCR. At $80 \%$ confluence, myoblasts were differentiated into myotubes by culturing in fusion medium consisting of 76\% DMEM Glutamax with $25 \mathrm{mM}$ glucose, 20\% M199 (5.5 mM), 2\% HEPES, and $1 \%$ Antibiotic-Antimycotic (100X), with $0.03 \mu \mathrm{g} / \mathrm{mL}$ zinc sulfate and $1.4 \mathrm{mg} / \mathrm{mL}$ Vitamin B12. Apo-transferrin $(100 \mu \mathrm{g} / \mathrm{mL})$ and insulin $(0.286 \mathrm{IU} / \mathrm{mL})$ was added to the fusion medium. After 4-5 days, the medium was switched to the same medium without apo-transferrin or insulin, with 2\% FBS (post-fusion media) and the cultures were continued for 3-5 days.

\section{Palmitate treatment}

Palmitate stock solution (200 mM) (C16, Sigma P9767) was prepared in 50\% ethanol and then diluted 25 times in a 10.5\% BSA solution. BSA (Sigma A8806) in serum-free essential alpha medium ( $(\mathrm{M}$ MM) was used as a carrier and control. Myotubes were incubated in $5.5 \mathrm{mM}$ glucose media for $22 \mathrm{~h}$ prior to the experiments. Myotubes were synchronized by serum shock 
(50\% FBS, 2h), washed with PBS, and incubated in $5.5 \mathrm{mM}$ glucose medium containing palmitate $(0.4 \mathrm{mM})$ or BSA (vehicle). Cultures were collected every $6 \mathrm{~h}$ for mRNA analysis and every $8 \mathrm{~h}$ for DNA and immunoblot analysis, starting from $12 \mathrm{~h}$ to $54 \mathrm{~h}$ after synchronization.

\section{Immunoblot analysis}

Myotube cultures were lysed in ice cold buffer A (1\% Protease Inhibitor Cocktail, $137 \mathrm{mmol} / \mathrm{L}$ $\mathrm{NaCl}, 2.7 \mathrm{mM} \mathrm{KCl}, 1 \mathrm{mM} \mathrm{MgCl} 2,5 \mathrm{mM} \mathrm{Na}_{4} \mathrm{P}_{2} \mathrm{O}_{7}, 0.5 \mathrm{mM} \mathrm{Na} \mathrm{VO}_{4}, 1 \%$ Triton X-100, 10\% glycerol, $20 \mathrm{mM}$ Tris, $10 \mathrm{mM} \mathrm{NaF}, 1 \mathrm{mM}$ EDTA, and $0.2 \mathrm{mM}$ phenylmethylsulfonyl fluoride, $\mathrm{pH} 7.8)$, followed by end-over-end rotation for $60 \min \left(4^{\circ} \mathrm{C}\right)$ and centrifugation at $12,000 \mathrm{~g}$ for $15 \min \left(4^{\circ} \mathrm{C}\right)$. Skeletal muscle biopsies were pulverized in liquid nitrogen and lysed in homogenization buffer A supplemented with $0.5 \%$ of NP- 40 and $0.02 \%$ of SDS, followed by end-over-end rotation for $60 \mathrm{~min}\left(4^{\circ} \mathrm{C}\right)$ and centrifugation at $3,000 \mathrm{~g}$ for $10 \mathrm{~min}\left(4^{\circ} \mathrm{C}\right)$. Protein concentration was determined using a Pierce BCA protein assay kit (\#23225, Thermo Fischer Scientific). Samples were prepared for SDS-PAGE with Laemmli buffer, separated on Criterion XT Bis-Tris 4-12\% gradient gels (Bio-Rad, Hercules, CA) and transferred to PVDF membranes (Merck). Ponceau staining was performed and the results were normalized to the total amount of protein per lane. Western blot was performed using primary antibodies (1:1000 concentration) in tris-buffered saline (TBS) containing $0.1 \%$ bovine serum albumin (BSA) and 0.1\% $\mathrm{NaN}_{3}$. Bionordika antibodies for Acetyl-Histone H3 Lysine 27 (\#8173S), AcetylatedLysine (\#9441S) and Histone H3 (\#4499T) were used. Species-appropriate horseradish peroxidase conjugated secondary antibodies were used at a concentration of $1: 25,000$ in $5 \%$ skimmed milk in TBS-Tween. Proteins were visualized by chemiluminescence (\#RPN2232 ECL and \#RPN2235 ECL select Western blotting detection reagent - GE Healthcare, Little Chalfont, U.K.) and quantified using ImageLab software v. 5.2.1 (BioRad).

\section{RNA extraction and RNA sequencing}


Total RNA from myotube cultures was isolated with Trizol Reagent using a kit (Life Technologies; Cat \#15596-018,) and extracted using a miRNAeasy kit (Qiagen; Cat \#217004).

Total RNA concentration was quantified using a NanoDrop ND-1000 Spectrophotometer (Thermo Fisher Scientific, Waltham, MA). Aliquots of RNA ( $1 \mu \mathrm{g})$ were processed using the Illumina TruSeq Stranded Total RNA with Ribo-Zero Gold protocol (Illumina) as described (22). Total RNAs were depleted for ribosomal RNA, fragmented, and cDNA was synthesized using SuperScript III Reverse Transcriptase (Thermo Fisher Scientific). cDNA was subjected to AMPure beads (Beckman Coulter) and adenylated to prime for adapter ligation. DNA fragments were amplified using PCR with the following settings: $30 \mathrm{~s}, 98^{\circ} \mathrm{C} ;\left(10 \mathrm{~s}, 98^{\circ} \mathrm{C} ; 30 \mathrm{~s}\right.$, $\left.60^{\circ} \mathrm{C} ; 30 \mathrm{~s}, 72^{\circ} \mathrm{C}\right) \times 9-13$ cycles; $5 \mathrm{~min}, 72^{\circ} \mathrm{C}$, followed by a final cleanup. The cycle number was set to prevent saturation and overamplification of individual samples. Libraries were quality-controlled using a Bioanalyzer instrument (Agilent Technologies). Libraries were subjected to 100-bp single-end sequencing on the X Ten platform (Illumina) at the Beijing Genomics Institute (BGI; Hong Kong, China).

\section{Processing of RNA-seq samples}

RNA-seq reads $(\bar{n} \approx 38.5 \mathrm{M})$ from FASTQ files were quality-trimmed using Trim_Galore (v0.4.3). Trimmed reads were aligned using STAR (v2.5.3a) (23) aligner with Ensembl human annotation (GRCh38, release 92) (24) and gene features were counted using featureCounts (25) from subread (v1.5.2) package resulting in 23.6 $\mathrm{M}$ and 17.9 $\mathrm{M}$ reads on average, respectively. The lowly expressed genes were discarded from downstream analysis using filterByExpr function from edgeR package resulting 16229 genes (26). The $\log C P M$ (count per million) values for each gene were calculated using limma's voom function while correcting for batch effect from participants using duplicateCorrelation function (27).

H3K27 acetylation chromatin immunoprecipitation and sequencing (ChIP-seq) 
H3K27 ChIP-sequencing was performed as described (28). Myotubes were cross-linked in 1\% formaldehyde in PBS for $10 \mathrm{~min}$ at room temperature followed by quenching with glycine (0.125 M). Cells were washed with PBS and harvested in $1 \mathrm{ml}$ SDS Buffer (50 mM Tris-HCl (pH 8), $100 \mathrm{mM}$ NaCl, $5 \mathrm{mM}$ EDTA (pH 8.0), 0.2\% NaN3, 0.5\% SDS, $0.5 \mathrm{mM}$ phenylmethylsulfonyl fluoride) and subjected to centrifugation (6 min at $250 \mathrm{x} \mathrm{g}$ ). Pelleted nuclei were lysed in $1.5 \mathrm{ml}$ ice-cold IP Buffer (67 mM Tris-HCl (pH 8), $100 \mathrm{mM} \mathrm{NaCl}, 5 \mathrm{mM}$ EDTA (pH 8.0), 0.2\% NaN3, 0.33\% SDS, 1,67\% Triton X-100, 0.5 mM phenylmethylsulfonyl fluoride) and sonicated (Diagenode, Biorupter) to an average length of 200-500 bp. Before starting the ChIP experiment, chromatin was cleared by centrifugation for $30 \mathrm{~min}$ at $20,000 \mathrm{x}$ g. For each ChIP, 2-10 $\mu$ g DNA was combined with $2.5 \mu$ g antibody for H3K27ac (Ab4729), and incubated with rotation at $4{ }^{\circ} \mathrm{C}$ for $16 \mathrm{~h}$. Immunoprecipitation was performed by incubation with Protein G Sepharose beads (GE healthcare) for $4 \mathrm{~h}$ followed by three washes with low-salt buffer (20 mM TrisHCl (pH 8.0), 2 mM EDTA (pH 8.0), 1\% Triton X-100, 0.1\% SDS, 150 $\mathrm{mM} \mathrm{NaCl}$ ) and two washes with high-salt buffer (20 mM Tris-HCl (pH 8.0), 2 mM EDTA (pH 8.0), $1 \%$ Triton X-100, 0.1\% SDS, $500 \mathrm{mM} \mathrm{NaCl}$ ). Chromatin was de-cross-linked in $120 \mu \mathrm{l}$ $1 \% \mathrm{SDS}$ and $0.1 \mathrm{M} \mathrm{NaHCO}_{3}$ for $6 \mathrm{~h}$ at $65^{\circ} \mathrm{C}$, and DNA was subsequently purified using Qiagen MinElute PCR purification kit. For library preparation and sequencing, 3-10 ng of immunoprecipitated DNA was used to generate adapter-ligated DNA libraries using the NEBNext ${ }^{\circledR}$ Ultra DNA library kit for Illumina (New England Biolabs, E7370L) and indexed multiplex primers for Illumina sequencing (New England Biolabs, E7335). The PCR cycle number for each library amplification was optimized by running $10 \%$ of the library DNA in a real-time PCR reaction using Brilliant III Ultra-fast SYBR Green QPCR Master Mix (AH Diagnostic) and a C1000 Thermal cycler (Bio-Rad). DNA libraries were sequenced on a HiSeq2000 by 50 -bp single-end sequencing at the National High- Throughput Sequencing Centre (University of Copenhagen, Denmark). 


\section{Processing of H3K27ac ChIP-seq samples}

H3K27ac ChIP-Seq samples quality was assessed using FASTQC software and quality trimmed with trimmomatic (v0.32) (29) on the same parameters to clip adapters to remove low quality sequences using a minimum quality of 30, a sliding window of 5 and a minimum length of 40 bp. Reads were mapped to $H$. sapiens reference genome using Bowtie2 (v2.3.2-foss-2016b) aligner (30). Duplicate removal was performed using samtools (v1.5-foss-2016b) (31) and then BAM files were subjected to peak count using MACS2 software (v2.1.0) (32) for broad peaks using a q-value of 0.01 and a shift of $147 \mathrm{bp}$. Called peaks were quantified with featureCounts (v1.6.3) (25) and associated to closest genes using RGmatch software (33), mapping regions to the transcriptomic start site and the promoter of the first exon. The resulting peak matrix was Reads Per Kilobase of transcript, per Million mapped reads (RPKM) normalized and batch corrected using ComBat (34) to correct for sequencing lane bias.

\section{Skeletal muscle transcriptome in individuals with obesity}

Datasets containing samples from individuals with normal BMI or obesity (BMI $>30 \mathrm{~kg} / \mathrm{m}^{2}$ ) were collected from the GEO database. Five datasets were identified: GSE43760, GSE45745, GSE73034, GSE73078 and GSE135066 (Table 2). Data were downloaded and $\log 2$ and quantile transformations were applied when necessary. Datasets were annotated and merged based on ENSEMBL names. A linear regression model was fitted using empirical Bayes statistics for differential expression with the limma package (27), blocking for batch effects induced by inter-dataset differences.

\section{Bioinformatic analysis}

Time series samples were analyzed with the R Package RAIN (35) to capture the rhythmic oscillations and determine peak times of the gene expression and acetylated regions. Rhythmicity was determined based on a 24h longitudinal period. Genes and H3K27 acetylated regions were considered rhythmic when $\mathrm{FDR}<0.1$. Limma $\mathrm{R}$ package (27) was used to 
determine differential gene expression and histone acetylation. The effect of time was blocked using a linear function to study the independent effect of palmitate. The effect of palmitate and obesity was considered significant when FDR $<0.1$. Enrichment of functional clusters was performed on significant genes $(\mathrm{FDR}<0.1)$ using Functional Annotation Clustering from DAVID bioinformatic resources $6.8(36 ; 37)$. Functional clusters were selected when biological processes (BP) were included in the cluster and the enrichment score was greater than 1.3. pvalues are adjusted for multiple testing by FDR and considered significant when below 0.1 .

\section{Statistics}

Statistical analyses were performed using GraphPad Prism 9.0.0 (GraphPad Software). Normality was tested using the Shapiro-Wilk normality test. Data are presented as mean $\pm \mathrm{SEM}$. Two-way ANOVA with Sidak's post hoc test was used to determine the effect of palmitate on total histone H3, histone H3K27 acetylation and total acetylated lysine in skeletal muscle cells. Student's unpaired $t$-test was performed to determine the effect of obesity on total histone H3 and histone $\mathrm{H} 3 \mathrm{~K} 27 \mathrm{ac}$ in skeletal muscle biopsies. $\mathrm{P}<0.05$ was considered significant. 


\section{RESULTS}

\section{Palmitate treatment attenuates circadian oscillations in primary human myotubes}

Primary skeletal muscle cells were synchronized, treated with palmitate or BSA-vehicle, and harvested every 6h (Figure 1A). Myotubes treated with BSA-vehicle presented 3,933 rhythmic transcripts (24\% of all transcripts) compared to 2,210 rhythmic transcripts in cells exposed to palmitate (14\% of all transcripts) (Figure 1B) (FDR $<0.1)$. Core clock genes including BMAL1, CIART, DBP, CRY1, CRY2, NR1D1, NR1D2, PER1, PER2 and PER3, were among the transcripts that were rhythmic in both conditions (Figure 1C and 1D). NPAS2 and CLOCK were rhythmic in BSA-vehicle-treated, but not in palmitate-treated myotubes. In BSA-vehicle-treated myotubes, $33 \%$ of the genes peaked at $6 \mathrm{~h}$, whereas $11 \%$ peaked at $12 \mathrm{~h}, 31 \%$ at $18 \mathrm{~h}$ and $25 \%$ at 24h. In palmitate-treated myotubes, $42 \%$ of the genes peaked at $6 \mathrm{~h}$, whereas $18 \%$ peaked at $12 \mathrm{~h}, 25 \%$ at $18 \mathrm{~h}$ and $15 \%$ at $24 \mathrm{~h}$ (Figure $1 \mathrm{E}$ ). Thus, palmitate influences the number of rhythmic genes and induces a shift in the peak time of gene expression.

\section{Distinct rhythmic gene ontologies in BSA-vehicle- and palmitate-treated human myotubes}

Comparison of rhythmic genes in BSA-vehicle- and palmitate-treated myotubes revealed 730 common genes (Figure 2A). Cluster enrichment analysis for biological processes on rhythmic genes specific for BSA-vehicle treatment showed an enrichment for pathways involved in ribosomal proteins, protein translation, protein ubiquitination and cell division (Figure 2B). Rhythmic genes specific for palmitate-treated cells were associated with genes annotated to several classifications including transcription and transcription regulation, Jumonji C (JmjC) activity and serine/threonine protein kinase activity (Figure 2B). Analysis of the 730 common rhythmic genes revealed an enrichment of clusters involved in circadian regulation of gene expression, regulation of circadian rhythms, and regulation of transcription (Figure 2B).

Palmitate induces differential expression of rhythmic genes involved in lipid metabolism 
Gene exhibiting rhythmic behavior in either BSA-vehicle, palmitate or both conditions $(5,413$ genes, Figure 2A) were analyzed for differential expression, independent of time. Among all cycling genes, palmitate affected the expression of 468 genes, with 292 genes upregulated and 176 downregulated genes (Figure $3 \mathrm{~A}$ and $3 \mathrm{~B})(\mathrm{FDR}<0.1)$. Comparison of differentially expressed genes to total rhythmic genes revealed 305 genes cycling in BSA-vehicle-treated, but not palmitate-treated cells, 110 genes cycling in palmitate-treated, but not BSA-vehicle-treated cells, and 53 genes cycling in both conditions (Figure 3C). Cluster enrichment analysis on differentially expressed rhythmic genes revealed that palmitate affected genes involved in the regulation of lipid metabolism and regulation of cell growth (Figure 3D).

\section{Palmitate affects histone $\mathrm{H3}$ lysine $\mathrm{K} 27$ acetylation in a rhythmic manner}

Palmitate treatment was associated with rhythmicity of genes involved in regulation of transcription in skeletal muscle cells (Figure 2B). Thus, to explore a potential mechanism for altered temporal regulation of transcription, we investigated whether palmitate treatment alters histone modifications. Relative abundance of total histone H3, total acetylated lysine and the marker of active enhancers histone $\mathrm{H} 3$ lysine 27 (H3K27ac) were assessed over a 48h period in cells incubated in the presence or absence of palmitate. Histone H3 protein abundance was unaffected by time or palmitate treatment (Figure 4A). Conversely, histone H3K27ac was affected in a time-dependent manner and influenced by palmitate treatment (Figure 4B). The relative abundance of histone $\mathrm{H} 3 \mathrm{~K} 27 \mathrm{ac}$ was increased after palmitate treatment, with the largest increase observed $32 \mathrm{~h}$ after synchronization (Figure 4B). Total lysine acetylation was decreased after palmitate treatment (Figure 4C), suggesting a specific enrichment in histone H3K27ac in response to palmitate treatment. Representative blots are shown in Figure 4D.

\section{Palmitate attenuates rhythmic behavior of $\mathrm{H3K27}$ acetylated regions}

Genome-wide analysis of histone H3K27ac was performed by chromatin immunoprecipitation (ChIP) and sequencing of synchronized skeletal muscle cells treated with palmitate or BSA- 
vehicle (Figure 5A). We identified $>127 \mathrm{k}$ regions with acetylated peaks that were distributed throughout the whole genome. From these, 6,132 regions were annotated to a gene and used for further analysis. In BSA-vehicle treated myotubes, we identified 1,018 rhythmic regions, compared to 850 rhythmic regions in palmitate-treated myotubes (Figure 5B) $(\mathrm{FDR}<0.1)$. Between the two treatments, 229 common rhythmic regions were identified (Figure 5C). In BSA-vehicle treated myotubes, there were 147 rhythmic regions peaking at the $24 \mathrm{~h}$ timepoint ( $14 \%$ of rhythmic regions), 51 peaking at $32 \mathrm{~h}(5 \%)$ and 820 peaking at $40 \mathrm{~h}$ after synchronization (81\%) (Figure 5D), while in palmitate-treated myotubes, there were 43 regions peaking at $24 \mathrm{~h}(5 \%), 89$ regions peaking at $32 \mathrm{~h}(10 \%)$ and 718 regions peaking at $40 \mathrm{~h}$ after synchronization (85\%) (Figure 5D). We performed a differential acetylation analysis on the 1,639 total cycling regions and observed that 708 regions were differentially acetylated after palmitate treatment $(\mathrm{FDR}<0.1)$ (Figure 5E). From those, 118 regions presented increased acetylation, while 590 presented reduced acetylation (Figure 5E). Our results suggest that the acetylation of specific $\mathrm{H} 3 \mathrm{~K} 27 \mathrm{ac}$ enhancer regions is regulated in a circadian manner. Our results indicate that changes in $\mathrm{H} 3 \mathrm{~K} 27 \mathrm{ac}$ enhancer regions induced by palmitate could be responsible of changes in the rhythmicity of gene expression.

\section{Changes in rhythmic acetylation of enhancers affect genes involved in lipid metabolism}

We identified the genes with both rhythmic transcript profiles and rhythmic H3K27ac regions to determine whether enhancer rhythmic acetylation coincided with rhythmic transcriptomics (Figure 6A). We identified 267 genes in BSA-vehicle-treated myotubes and 106 genes in palmitate-treated myotubes, with 15 common genes between the treatments. Of these, 174 genes were unique to BSA-vehicle-treated myotubes, and 47 were unique to palmitate-treated myotubes (Figure 6B). Cluster enrichment analysis showed only DNA repair as a cluster enriched for the 174 genes unique to BSA, and protein phosphorylation and angiogenesis as enriched clusters for the 47 unique genes for palmitate. 


\section{Obesity does not alter histone H3K27 acetylation in skeletal muscle}

Abundance of $\mathrm{H} 3$ protein and $\mathrm{H} 3 \mathrm{~K} 27 \mathrm{ac}$ was unaltered in skeletal muscle of men with obesity versus normal weight (Figure 7A-7C). Nevertheless, we found that obesity affected the expression of 406 genes (FDR $<0.1)$ in human skeletal muscle (Figure 7D), with 14 and 12 of these showing changes in mRNA expression and H3K27ac, respectively in palmitate-treated primary myotubes (Figure 7E). Only one gene, Transcriptional enhancer factor TEF-1 (TEAD1), was influenced by both human obesity (mRNA) and palmitate-treatment (at the mRNA and H3K27 acetylation level). TEAD1 is a ubiquitous transcriptional enhancer factor and its protein transactivates a wide variety of genes. 


\section{DISCUSSION}

The circadian clock is a major regulator of whole-body metabolism through the control of gene expression, hormone levels, food intake and energy expenditure $(7 ; 38 ; 39)$. Circadian disruption is linked to metabolic disorders such as obesity and type 2 diabetes (8). An acute palmitate exposure disrupts core clock gene expression in skeletal muscle (3), consistent with fatty acid-induced clock disturbances in liver and adipose tissue (5; 40). However, the implication of these lipid-induced disturbances on the regulation of core clock and clockcontrolled genes remains largely unexplored. In hepatocytes and adipocytes, palmitate exposure disrupts circadian gene oscillations by preventing BMAL1 deacetylation and activation and interfering with the CLOCK:BMAL1 interaction (40-42). Here, we report that palmitate reduced the total number of rhythmic transcripts in primary human skeletal muscle cells. Palmitate repressed rhythmicity of genes involved in protein translation and transport, and induced rhythmicity in genes involved in regulation of transcription. Collectively, our results have physiological implications by linking an oversupply of nutrients in the form of saturated fatty acids to the circadian machinery and the control of metabolism.

Long term palmitate exposure has cytotoxic effects and induces insulin resistance $(43 ; 44)$. These disturbances coincide with changes in transcription and altered lipid metabolism (40; 45; 46). An increase in fatty acid levels in hepatocytes promotes lipid oxidation, leading to an increased production of acetyl-CoA (47). Acetyl-CoA derived from lipid oxidation is the predominant contributor to the global acetyl-CoA pool, with increased acetyl-CoA levels promoting histone acetylation (47). Histone acetylation is one of the most prominent marks leading to activation of gene expression (8). Palmitate treatment decreased total lysine acetylation, concomitant with changes in rhythmicity and increased histone H3K27ac. Our results suggest that palmitate specifically regulates $\mathrm{H} 3 \mathrm{~K} 27 \mathrm{ac}$ independently of changes in total acetylation. Histone acetyltransferases (HAT) and histone deacetylases (HDAC) are enzymes that regulate histone and lysine acetylation (8). Sirtuins (SIRT) are NAD ${ }^{+}$-dependent HDACs 
that sense cellular energy metabolism and follow a circadian pattern (48). Components of the core clock machinery, CLOCK:BMAL1, coexist with SIRT1 in a chromatin regulatory complex (48). CLOCK can act as a HAT, with specificity for H3 and H4 (16), and interact with SIRT1 to regulate acetylation and deacetylation of BMAL1, respectively, which is essential for circadian regulation of gene expression (17). Thus, palmitate may alter $\mathrm{NAD}^{+}$levels, SIRT1 activity, and CLOCK:BMAL1 action, which may consequently alter histone H3K27ac.

We observed circadian oscillations in the levels histone H3K27ac in primary human muscle cells, supporting the notion that histone modifications are under circadian regulation $(19 ; 49$; 50). Palmitate-treatment altered global H3K27ac levels, consistent with previous evidence that palmitate acetylates enhancer regions regulating lipid metabolism in skeletal muscle and liver cells $(28 ; 51)$. Changes in histone $\mathrm{H} 3$ acetylation are an underlying mechanism regulating rhythmic transcriptional activity in mouse liver (52). However, histone acetylation and specifically histone $\mathrm{H} 3 \mathrm{~K} 27 \mathrm{ac}$ is likely accompanied by parallel changes in other covalent modifications that also regulate transcription (53). Changes in other histone marks, DNA methylation, mRNA stability and/or post-transcriptional RNA processing may contribute to the transcript oscillations, even in the absence of enhancer regulation.

Our finding that acute palmitate treatment increased H3K27ac in cultured myotubes suggests that an acute elevated circulating lipid levels may be a contributing factor to this histone modification. Changes in histone H3K27ac in skeletal muscle has been described in the context of aging, with increased expression of genes regulating extracellular matrix structure and organizations (54). We found histone H3K27ac was associated with changes in genes involved in fatty acid metabolism, consistent with earlier reports in pancreas and colon of dietinduced obese mice $(51 ; 55)$. Conversely, histone H3K27ac was unaltered in skeletal muscle of men with obesity as compared to men with normal weight. Thus, lipid-induced changes in 
histone $\mathrm{H} 3 \mathrm{~K} 27 \mathrm{ac}$, rather than obesity or insulin resistance per se may contribute to the metabolic dysregulation observed in skeletal muscle.

In summary, the saturated fatty acid palmitate disrupts circadian transcriptomics in primary human myotubes. Our results provide a link between nutrient overload, disruptions of circadian rhythms, and metabolic pathways. Increased histone H3K27ac in palmitate-treated primary human myotubes suggests a specific role for this epigenetic mark in the transcriptional changes that occur in peripheral tissues in response to lipid-overload. Disruption of circadian rhythms in skeletal muscle due to lipid overload may lead to genomic changes that influence metabolism. Thus, dietary, or therapeutic modulation of lipid levels, a cornerstone in the treatment of metabolic disorders, may prevent circadian misalignment in peripheral tissues. 


\section{ACKNOWLEDGEMENTS}

The authors are supported by grants from the Novo Nordisk Foundation (NNF14OC0011493, NNF17OC0030088), Swedish Diabetes Foundation (DIA2018-357, DIA2018-336), Swedish

Research Council (2015-00165, 2018-02389), KID-funding (2-3591/2014), the Strategic

Research Program in Diabetes at Karolinska Institutet (2009-1068), Marie Skłodowska-Curie Actions (European Commission, 704978), EFSD European Research programme on New Targets for Type 2 Diabetes and the Stockholm County Council (SLL20150517, SLL20170159, SLL20190173). Additional support was received from the Novo Nordisk Foundation Center for Basic Metabolic Research at the University of Copenhagen (NNF18CC0034900).

\section{AUTHOR CONTRIBUTIONS}

L.S.P., A.A., B.M.G, R.B, A.K, N.J.P. and J.R.Z. devised the study concept and design. L.S.P., A.A., A.K, N.J.P. and J.R.Z. drafted the manuscript. All authors critically revised the manuscript for important intellectual content. L.S.P., A.A, and N.J.P. did the statistical analysis. E.N. measured the anthropometrics and collected the skeletal muscle biopsy material. L.S.P., B.M.G. and N.J.P. performed the muscle culture experiments and gene analysis. L.S.P. and A.V.C. performed the Western Blot analysis. R.B. and A.A. acquired and processed the RNAseq measurements. L.S.P. and B.M.G. performed sample preparation and ChIP Seq analysis. L.S.P., A.A., S.C.G., A.C., performed bioinformatic analysis. All authors analyzed and interpreted data, and provided administrative, technical, and material support. L.S.P. and J.R.Z. had full access to original data, and all authors to the results. J.R.Z. supervised the study. 


\section{REFERENCES}

1. Kelley DE, Goodpaster B, Wing RR, Simoneau JA: Skeletal muscle fatty acid metabolism in association with insulin resistance, obesity, and weight loss. Am J Physiol 1999;277:E1130-1141

2. Hsieh MC, Yang SC, Tseng HL, Hwang LL, Chen CT, Shieh KR: Abnormal expressions of circadian-clock and circadian clock-controlled genes in the livers and kidneys of longterm, high-fat-diet-treated mice. Int J Obes (Lond) 2010;34:227-239

3. Sardon Puig L, Pillon NJ, Naslund E, Krook A, Zierath JR: Influence of obesity, weight loss, and free fatty acids on skeletal muscle clock gene expression. Am J Physiol Endocrinol Metab 2020;318:E1-E10

4. Tahira K, Ueno T, Fukuda N, Aoyama T, Tsunemi A, Matsumoto S, Nagura C, Matsumoto T, Soma M, Shimba S, Matsumoto Y: Obesity alters the expression profile of clock genes in peripheral blood mononuclear cells. Arch Med Sci 2011;7:933-940

5. Vieira E, Ruano E, Figueroa AL, Aranda G, Momblan D, Carmona F, Gomis R, Vidal J, Hanzu FA: Altered clock gene expression in obese visceral adipose tissue is associated with metabolic syndrome. PLoS One 2014;9:e111678

6. Wefers J, van Moorsel D, Hansen J, Connell NJ, Havekes B, Hoeks J, van Marken Lichtenbelt WD, Duez H, Phielix E, Kalsbeek A, Boekschoten MV, Hooiveld GJ, Hesselink MKC, Kersten S, Staels B, Scheer F, Schrauwen P: Circadian misalignment induces fatty acid metabolism gene profiles and compromises insulin sensitivity in human skeletal muscle. Proc Natl Acad Sci U S A 2018;115:7789-7794

7. Qian J, Morris CJ, Caputo R, Wang W, Garaulet M, Scheer F: Sex differences in the circadian misalignment effects on energy regulation. Proc Natl Acad Sci U S A 2019;116:23806-23812

8. Kim YH, Lazar MA: Transcriptional control of circadian rhythms and metabolism: A matter of time and space. Endocr Rev 2020;41:707-732

9. Dominguez F, Fuster V, Fernandez-Alvira JM, Fernandez-Friera L, Lopez-Melgar B, Blanco-Rojo R, Fernandez-Ortiz A, Garcia-Pavia P, Sanz J, Mendiguren JM, Ibanez B, Bueno H, Lara-Pezzi E, Ordovas JM: Association of Sleep Duration and Quality With Subclinical Atherosclerosis. J Am Coll Cardiol 2019;73:134-144

10. Rajaratnam SM, Howard ME, Grunstein RR: Sleep loss and circadian disruption in shift work: health burden and management. Med J Aust 2013;199:S11-15

11. van Drongelen A, Boot CR, Merkus SL, Smid T, van der Beek AJ: The effects of shift work on body weight change - a systematic review of longitudinal studies. Scand J Work Environ Health 2011;37:263-275

12. Kettner NM, Mayo SA, Hua J, Lee C, Moore DD, Fu L: Circadian dysfunction induces leptin resistance in mice. Cell Metab 2015;22:448-459

13. Turek FW, Joshu C, Kohsaka A, Lin E, Ivanova G, McDearmon E, Laposky A, LoseeOlson S, Easton A, Jensen DR, Eckel RH, Takahashi JS, Bass J: Obesity and metabolic syndrome in circadian Clock mutant mice. Science 2005;308:1043-1045

14. Young MW: Time travels: A 40-year journey from Drosophila's clock mutants to human circadian disorders (Nobel Lecture). Angew Chem Int Ed Engl 2018;57:11532-11539

15. Mauvoisin D, Gachon F: Proteomics in circadian biology. J Mol Biol 2020;432:35653577

16. Doi M, Hirayama J, Sassone-Corsi P: Circadian regulator CLOCK is a histone acetyltransferase. Cell 2006;125:497-508

17. Hirayama J, Sahar S, Grimaldi B, Tamaru T, Takamatsu K, Nakahata Y, Sassone-Corsi P: CLOCK-mediated acetylation of BMAL1 controls circadian function. Nature 2007;450:1086-1090 
18. Naruse Y, Oh-hashi K, Iijima N, Naruse M, Yoshioka H, Tanaka M: Circadian and lightinduced transcription of clock gene Per1 depends on histone acetylation and deacetylation. Mol Cell Biol 2004;24:6278-6287

19. Sato S, Solanas G, Peixoto FO, Bee L, Symeonidi A, Schmidt MS, Brenner C, Masri S, Benitah SA, Sassone-Corsi P: Circadian reprogramming in the liver identifies metabolic pathways of aging. Cell 2017;170:664-677 e611

20. Vollmers C, Schmitz RJ, Nathanson J, Yeo G, Ecker JR, Panda S: Circadian oscillations of protein-coding and regulatory RNAs in a highly dynamic mammalian liver epigenome. Cell Metab 2012;16:833-845

21. Barres R, Kirchner H, Rasmussen M, Yan J, Kantor FR, Krook A, Naslund E, Zierath JR: Weight loss after gastric bypass surgery in human obesity remodels promoter methylation. Cell Rep 2013;3:1020-1027

22. Nylander V, Ingerslev LR, Andersen E, Fabre O, Garde C, Rasmussen M, Citirikkaya K, Baek J, Christensen GL, Aznar M, Specht L, Simar D, Barres R: Ionizing radiation potentiates high-fat diet-induced insulin resistance and reprograms skeletal muscle and adipose progenitor cells. Diabetes 2016;65:3573-3584

23. Dobin A, Davis CA, Schlesinger F, Drenkow J, Zaleski C, Jha S, Batut P, Chaisson M, Gingeras TR: STAR: ultrafast universal RNA-seq aligner. Bioinformatics 2013;29:15-21

24. Zerbino DR, Achuthan P, Akanni W, Amode MR, Barrell D, Bhai J, Billis K, Cummins C, Gall A, Giron CG, Gil L, Gordon L, Haggerty L, Haskell E, Hourlier T, Izuogu OG, Janacek SH, Juettemann T, To JK, Laird MR, Lavidas I, Liu Z, Loveland JE, Maurel T, McLaren W, Moore B, Mudge J, Murphy DN, Newman V, Nuhn M, Ogeh D, Ong CK, Parker A, Patricio M, Riat HS, Schuilenburg H, Sheppard D, Sparrow H, Taylor K, Thormann A, Vullo A, Walts B, Zadissa A, Frankish A, Hunt SE, Kostadima M, Langridge N, Martin FJ, Muffato M, Perry E, Ruffier M, Staines DM, Trevanion SJ, Aken BL, Cunningham F, Yates A, Flicek P: Ensembl 2018. Nucleic Acids Res 2018;46:D754-D761

25. Liao Y, Smyth GK, Shi W: featureCounts: an efficient general purpose program for assigning sequence reads to genomic features. Bioinformatics 2014;30:923-930

26. Robinson MD, McCarthy DJ, Smyth GK: edgeR: a Bioconductor package for differential expression analysis of digital gene expression data. Bioinformatics 2010;26:139-140

27. Ritchie ME, Phipson B, Wu D, Hu Y, Law CW, Shi W, Smyth GK: limma powers differential expression analyses for RNA-sequencing and microarray studies. Nucleic Acids Res 2015;43:e47

28. Williams K, Ingerslev LR, Bork-Jensen J, Wohlwend M, Hansen AN, Small L, RibelMadsen R, Astrup A, Pedersen O, Auwerx J, Workman CT, Grarup N, Hansen T, Barres $\mathrm{R}$ : Skeletal muscle enhancer interactions identify genes controlling whole-body metabolism. Nat Commun 2020;11:2695

29. Bolger AM, Lohse M, Usadel B: Trimmomatic: a flexible trimmer for Illumina sequence data. Bioinformatics 2014;30:2114-2120

30. Langmead B, Salzberg SL: Fast gapped-read alignment with Bowtie 2. Nat Methods 2012;9:357-359

31. Li H, Handsaker B, Wysoker A, Fennell T, Ruan J, Homer N, Marth G, Abecasis G, Durbin R, Genome Project Data Processing S: The sequence alignment/Map format and SAMtools. Bioinformatics 2009;25:2078-2079

32. Zhang Y, Liu T, Meyer CA, Eeckhoute J, Johnson DS, Bernstein BE, Nusbaum C, Myers RM, Brown M, Li W, Liu XS: Model-based analysis of ChIP-Seq (MACS). Genome Biol 2008;9:R137

33. Furio-Tari $\mathrm{P}$, Conesa A, Tarazona S: RGmatch: matching genomic regions to proximal genes in omics data integration. BMC Bioinformatics 2016;17:427 
34. Johnson WE, Li C, Rabinovic A: Adjusting batch effects in microarray expression data using empirical Bayes methods. Biostatistics 2007;8:118-127

35. Thaben PF, Westermark PO: Detecting rhythms in time series with RAIN. J Biol Rhythms 2014;29:391-400

36. Huang da W, Sherman BT, Lempicki RA: Bioinformatics enrichment tools: paths toward the comprehensive functional analysis of large gene lists. Nucleic Acids Res 2009;37:113

37. Huang da W, Sherman BT, Lempicki RA: Systematic and integrative analysis of large gene lists using DAVID bioinformatics resources. Nat Protoc 2009;4:44-57

38. Morris CJ, Purvis TE, Hu K, Scheer FA: Circadian misalignment increases cardiovascular disease risk factors in humans. Proc Natl Acad Sci U S A 2016;113:E1402-1411

39. Versteeg RI, Stenvers DJ, Kalsbeek A, Bisschop PH, Serlie MJ, la Fleur SE: Nutrition in the spotlight: metabolic effects of environmental light. Proc Nutr Soc 2016;75:451-463

40. Tal Y, Chapnik N, Froy O: Non-obesogenic doses of palmitate disrupt circadian metabolism in adipocytes. Adipocyte 2019;8:392-400

41. Tal Y, Chapnik N, Froy O: Non-obesogenic doses of fatty acids modulate the functionality of the circadian clock in the liver. Cell Mol Life Sci 2019;76:1795-1806

42. Tong X, Zhang D, Arthurs B, Li P, Durudogan L, Gupta N, Y in L: Palmitate inhibits SIRT1-dependent BMAL1/CLOCK interaction and disrupts circadian gene oscillations in hepatocytes. PLoS One 2015;10:e0130047

43. Makinen S, Nguyen YH, Skrobuk P, Koistinen HA: Palmitate and oleate exert differential effects on insulin signalling and glucose uptake in human skeletal muscle cells. Endocr Connect 2017;6:331-339

44. Pillon NJ, Frendo-Cumbo S, Jacobson MR, Liu Z, Milligan PL, Hoang Bui H, Zierath JR, Bilan PJ, Brozinick JT, Klip A: Sphingolipid changes do not underlie fatty acid-evoked GLUT4 insulin resistance nor inflammation signals in muscle cells. J Lipid Res 2018;59:1148-1163

45. Dimopoulos N, Watson M, Sakamoto K, Hundal HS: Differential effects of palmitate and palmitoleate on insulin action and glucose utilization in rat L6 skeletal muscle cells. Biochem J 2006;399:473-481

46. Hall E, Volkov P, Dayeh T, Bacos K, Ronn T, Nitert MD, Ling C: Effects of palmitate on genome-wide mRNA expression and DNA methylation patterns in human pancreatic islets. BMC Med 2014;12:103

47. McDonnell E, Crown SB, Fox DB, Kitir B, Ilkayeva OR, Olsen CA, Grimsrud PA, Hirschey MD: Lipids reprogram metabolism to become a major carbon source for histone acetylation. Cell Rep 2016;17:1463-1472

48. Nakahata Y, Kaluzova M, Grimaldi B, Sahar S, Hirayama J, Chen D, Guarente LP, Sassone-Corsi P: The NAD+-dependent deacetylase SIRT1 modulates CLOCK-mediated chromatin remodeling and circadian control. Cell 2008;134:329-340

49. Feng D, Liu T, Sun Z, Bugge A, Mullican SE, Alenghat T, Liu XS, Lazar MA: A circadian rhythm orchestrated by histone deacetylase 3 controls hepatic lipid metabolism. Science 2011;331:1315-1319

50. Kim YH, Marhon SA, Zhang Y, Steger DJ, Won KJ, Lazar MA: Rev-erbalpha dynamically modulates chromatin looping to control circadian gene transcription. Science 2018;359:1274-1277

51. Nammo T, Udagawa H, Funahashi N, Kawaguchi M, Uebanso T, Hiramoto M, Nishimura W, Yasuda K: Genome-wide profiling of histone H3K27 acetylation featured fatty acid signalling in pancreatic beta cells in diet-induced obesity in mice. Diabetologia 2018;61:2608-2620 
52. Etchegaray JP, Lee C, Wade PA, Reppert SM: Rhythmic histone acetylation underlies transcription in the mammalian circadian clock. Nature 2003;421:177-182

53. Orphanides G, Reinberg D: A unified theory of gene expression. Cell 2002;108:439-451

54. Zhou J, So KK, Li Y, Li Y, Yuan J, Ding Y, Chen F, Huang Y, Liu J, Lee W, Li G, Ju Z, Sun H, Wang H: Elevated H3K27ac in aged skeletal muscle leads to increase in extracellular matrix and fibrogenic conversion of muscle satellite cells. Aging Cell 2019; 18:e12996

55. Li R, Grimm SA, Chrysovergis K, Kosak J, Wang X, Du Y, Burkholder A, Janardhan K, Mav D, Shah R, Eling TE, Wade PA: Obesity, rather than diet, drives epigenomic alterations in colonic epithelium resembling cancer progression. Cell Metab 2014;19:702711 


\section{FIGURE LEGENDS}

Figure 1. Palmitate attenuates the number of rhythmic transcripts in skeletal muscle. RNA-seq of synchronized primary human skeletal muscle myotubes $(n=7)$ treated with palmitate $(0.4 \mathrm{mM})$ or BSA-vehicle. A. Graphic representation of data collection B. Proportion of rhythmic genes identified (RAIN analysis, FDR $<0.1$ ). C. Correlation of rhythmic genes in palmitate and BSA-vehicle treated myotubes. Dotted line represents FDR of 0.1. D. Core clock genes expression in BSA-vehicle and palmitate treated myotubes. Results are mean \pm SEM. E. Percentage of rhythmic genes that peak at each phase $(6,12,18$ and $24 \mathrm{~h})$.

Figure 2. Enriched rhythmic gene ontologies are distinct for BSA-vehicle- and palmitatetreated myotubes. A. Rhythmic genes in BSA-vehicle-treated (blue) and palmitate-treated (purple) myotubes and the common rhythmic genes between the treatments. B. Cluster enrichment analysis for genes that are rhythmic in BSA-vehicle-treated myotubes, the palmitate-treated myotubes and the common rhythmic genes for between the treatments. Functional clusters were selected when biological processes (BP) were included in the cluster and the enrichment score was greater than 1.3. Dotted line represents FDR of 0.1 for the specific enriched pathways.

Figure 3. Palmitate induces changes in the expression of genes annotated to lipid metabolism gene ontology pathways in myotubes. A. Differential expression (DE) analysis of rhythmic genes in palmitate-treated myotubes (Limma, FDR $<0.1$ ) B. Heatmap of differentially expressed cycling genes $\mathbf{C}$. Common genes between DE, cycling in BSA-vehicletreated myotubes and cycling in palmitate-treated myotubes D. Functional annotation clustering for DE cycling genes in palmitate-treated myotubes. Functional clusters were selected when biological processes (BP) were included in the cluster and the enrichment score was greater than 1.3. Dotted line represents FDR of 0.1 for the specific enriched pathways. 


\section{Figure 4. Palmitate treatment increases histone H3K27 acetylation in a rhythmic manner}

in myotubes. Protein lysates were collected from BSA-vehicle- and palmitate-treated myotubes every $8 \mathrm{~h}$ from $24 \mathrm{~h}$ to $48 \mathrm{~h}$ after synchronization. Bar plots represent relative protein abundance of A. histone H3, B. histone H3K27ac, and C. total acetylated lysine in BSA-vehicle- and palmitate-treated myotubes. D. Representative immunoblots for H3, H3K27ac and total acetylated lysine. Results are mean \pm SEM, $n=6$, paired two-way ANOVA (time, palmitate), followed by Sidak's post hoc analysis. ${ }^{*} P \leq 0.05$ effect of palmitate, $\uparrow P \leq 0.05$ interaction.

Figure 5. Palmitate treatment reduces the number of cycling $\mathrm{H} 3 \mathrm{~K} 27$ acetylated regions in myotubes. H3K27ac ChIP-seq of synchronized primary human skeletal muscle myotubes $(n=4)$ treated with palmitate $(0.4 \mathrm{mM})$ or BSA-vehicle. A. Graphic representation of data collection B. Proportion of rhythmic regions identified (RAIN analysis, FDR $<0.1$ ). C. Rhythmic regions in BSA-vehicle-treated (blue) and palmitate-treated (purple) myotubes and the common rhythmic regions between the treatments. D. Cycling regions in the BSA-vehicle- (blue) or palmitate- (pink) treated cells where divided in three groups according the peak time $(24,32$, or 40 h). E. Differential acetylation analysis of rhythmic regions after palmitate treatment (limma, FDR<0.1).

Figure 6. Changes in enhancer rhythmic acetylation leads to changes in rhythmic transcriptomics in myotubes. A. Overlap of rhythmic genes (RNA-seq) and genes associated to rhythmic regions (H3K27ac ChIP-seq) in BSA-vehicle-treated (blue) and palmitate-treated (pink) myotubes. B. Unique gene overlap between the four groups

Figure 7. Total $\mathrm{H3}$ histone protein and H3K27ac and transcriptomic profiles in skeletal muscle biopsies from men with normal weight or obesity. Skeletal muscle biopsies were obtained from men with normal weight (Lean; $n=6$ ) or obesity (Obese; $n=6$ ). Protein lysates were collected and relative abundance of A. total histone H3 and B. histone H3K27ac was measured. Results are mean \pm SEM. ${ }^{*} \mathrm{P}<0.05$. Student's unpaired $t$-test was used. $\mathbf{C}$. 
Representative immunoblots for total histone $\mathrm{H} 3$ and histone $\mathrm{H} 3 \mathrm{~K} 27 \mathrm{ac}$ for men with normal weight (L) or obesity (O). Publicly available transcriptome data consisting of microarray profiling of skeletal muscle biopsies from individuals with obesity or normal body mass index were downloaded and processed as described in the methods section. D. The intersection of significant genes calculated with linear models in each independent study. One study did not report any genes passing the FDR threshold of 0.1. E. Comparison between differentially expressed cycling genes identified in the RNA-seq analysis, genes associated to differentially acetylated cycling regions in the H3K27ac ChIP-seq analysis, and differentially expressed genes in skeletal muscle from men with normal weight versus obesity. 
bioRxiv preprint doi: https://doi.org/10.1101/2021.02.23.432336; this version posted February 23, 2021. The copyright holder for this preprint (which was not certified by peer review) is the author/funder, who has granted bioRxiv a license to display the preprint in perpetuity. It is made available under aCC-BY-NC-ND 4.0 International license.

\section{Figure 1}

A

Palmitate
treatment

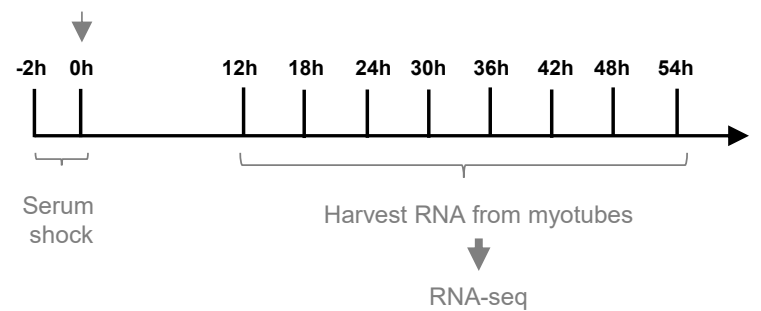

C

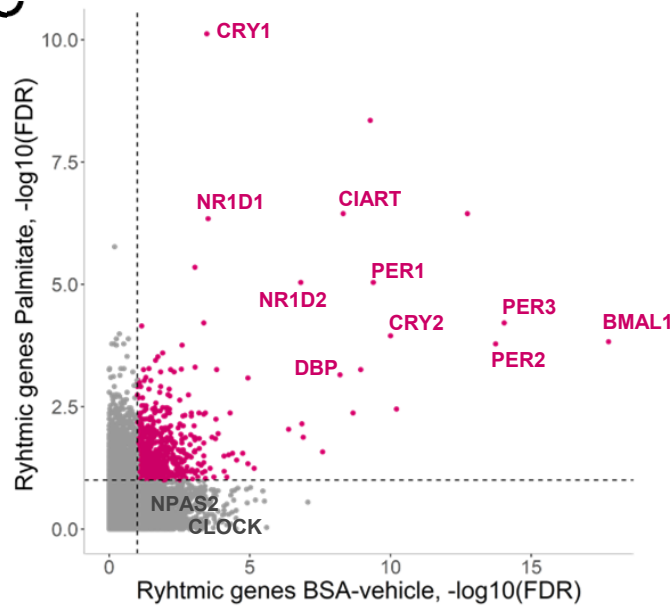

$E$
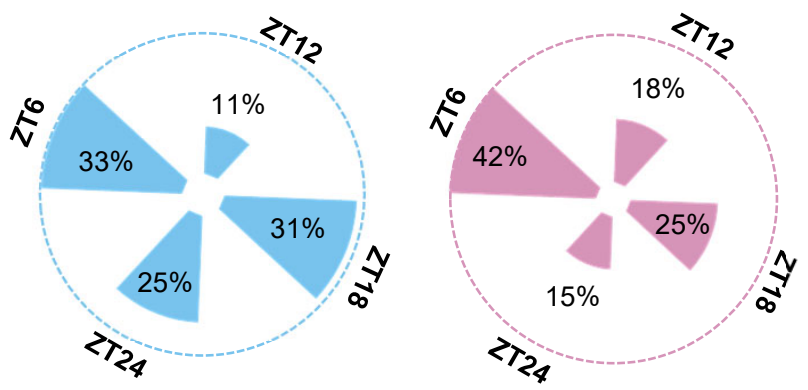

B

BSA-vehicle

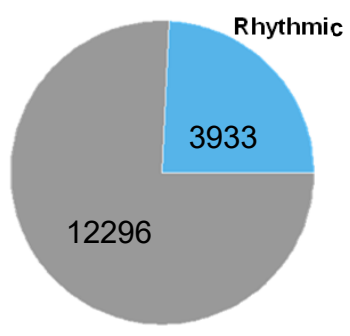

D

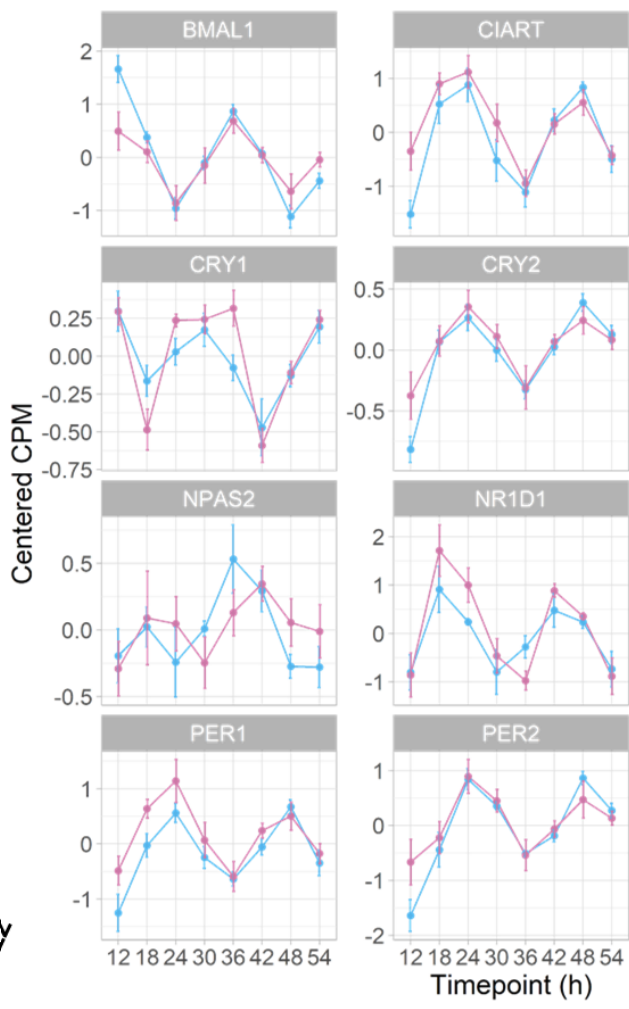

Palmitate

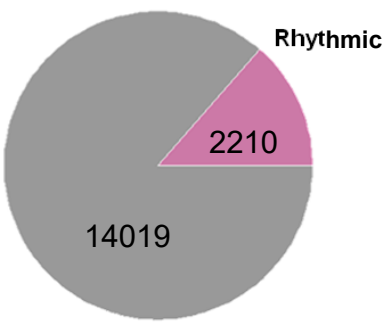

$\rightarrow B S A \rightarrow P A$
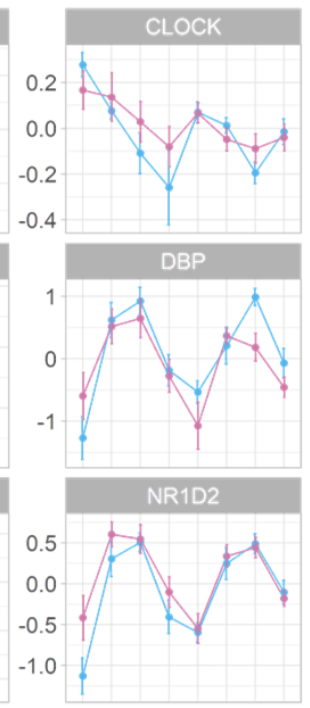

PER3

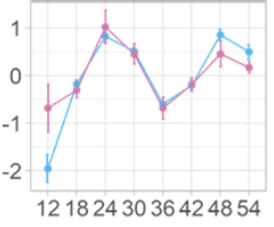


bioRxiv preprint doi: https://doi.org/10.1101/2021.02.23.432336; this version posted February 23, 2021. The copyright holder for this preprint (which was not certified by peer review) is the author/funder, who has granted bioRxiv a license to display the preprint in perpetuity. It is made available under aCC-BY-NC-ND 4.0 International license.

\section{Figure 2}

A

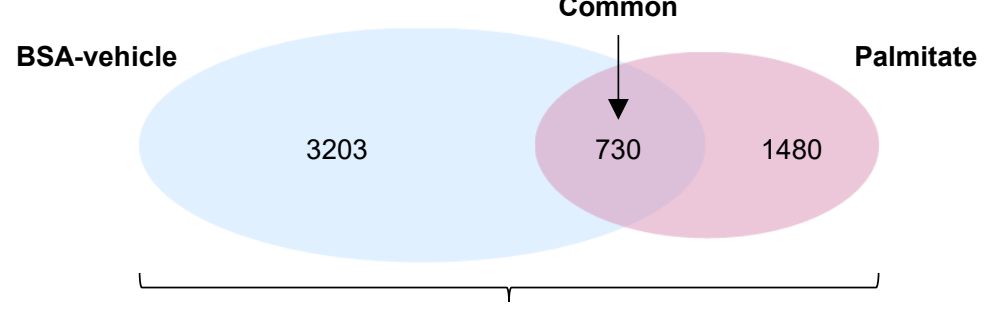

B

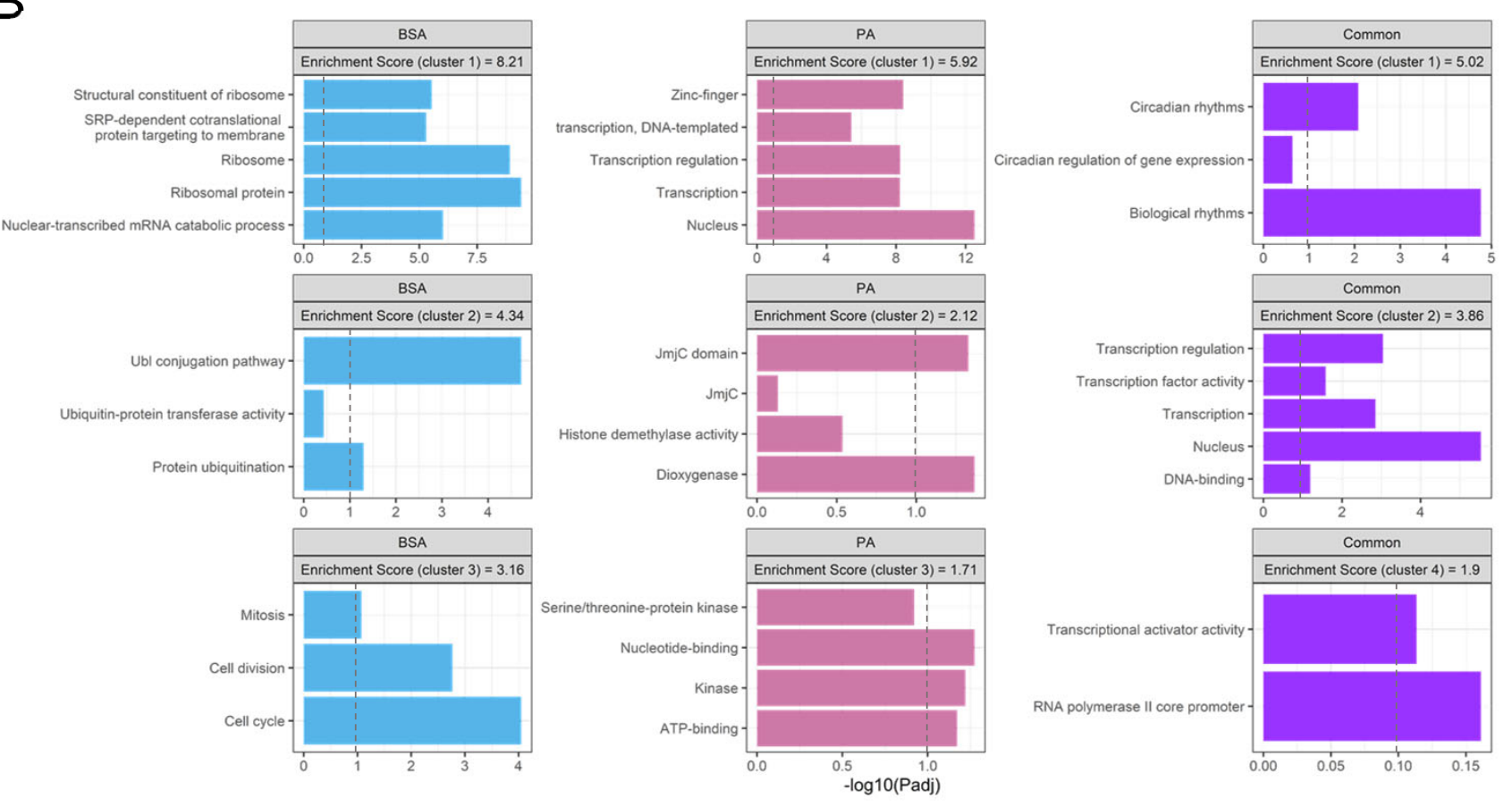


bioRxiv preprint doi: https://doi.org/10.1101/2021.02.23.432336; this version posted February 23, 2021. The copyright holder for this preprint (which was not certified by peer review) is the author/funder, who has granted bioRxiv a license to display the preprint in perpetuity. It is made available under aCC-BY-NC-ND 4.0 International license.

\section{Figure 3}

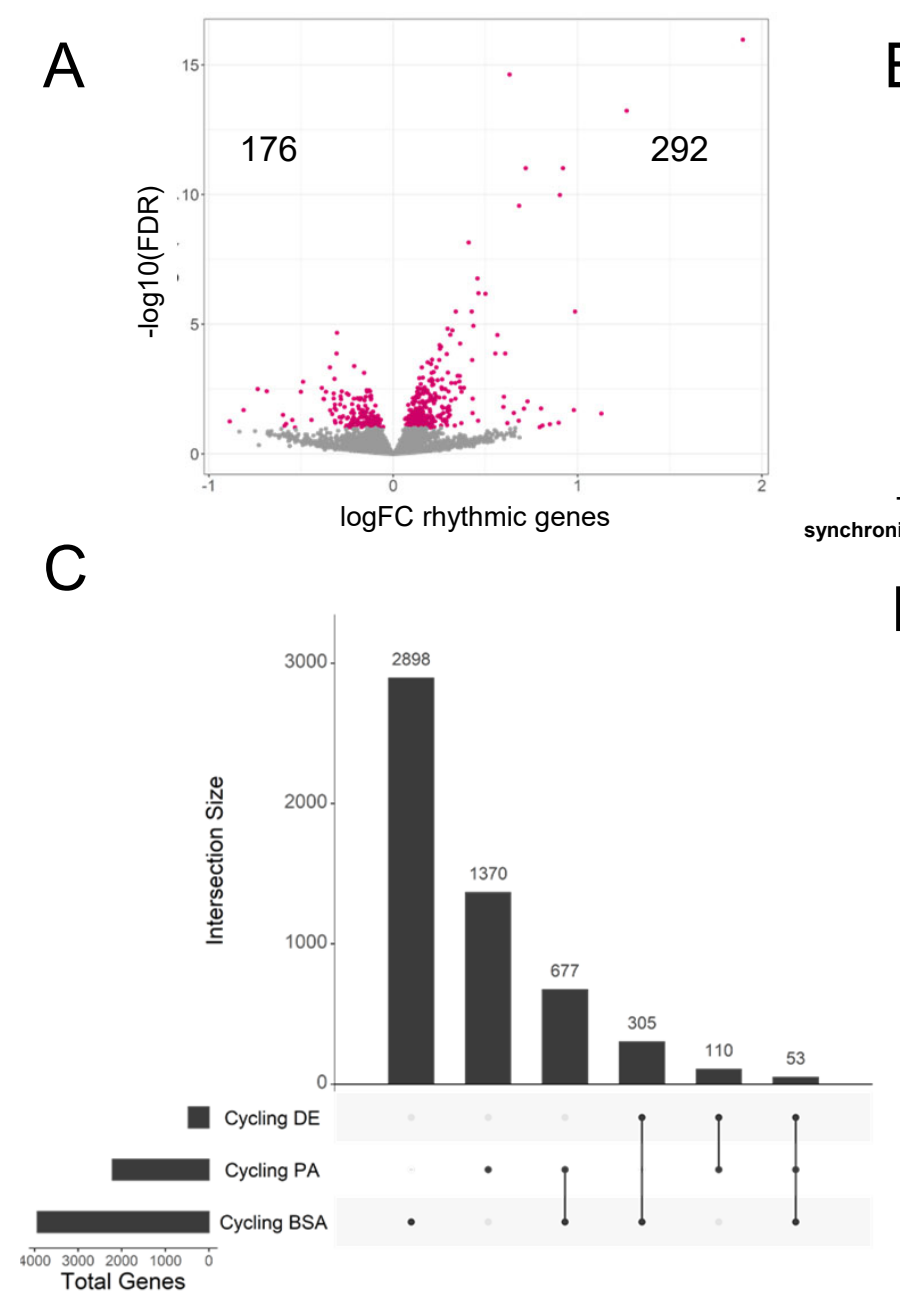

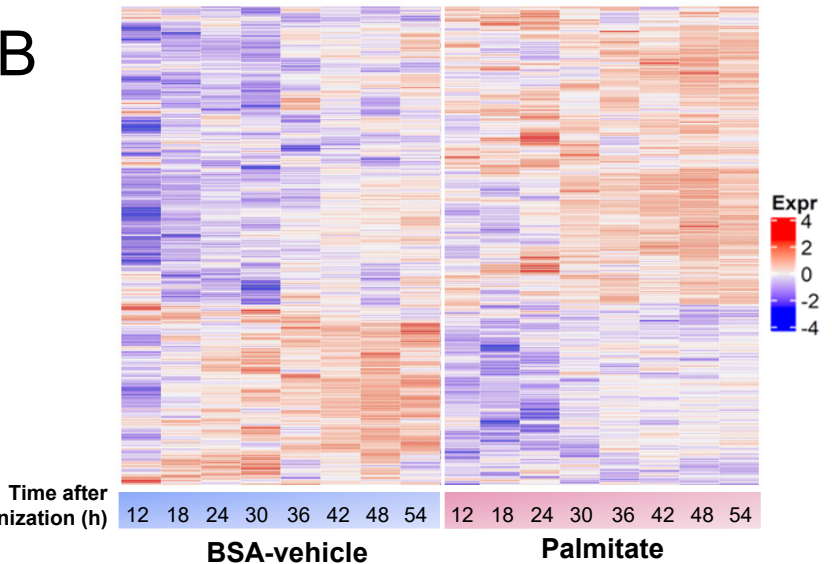

$\mathrm{D}$

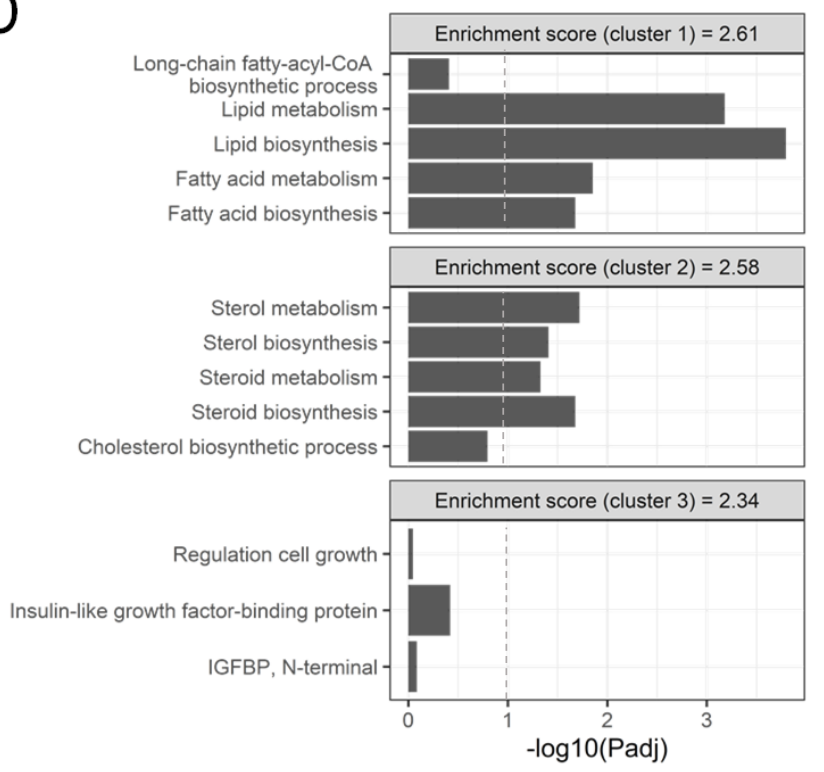




\section{Figure 4}

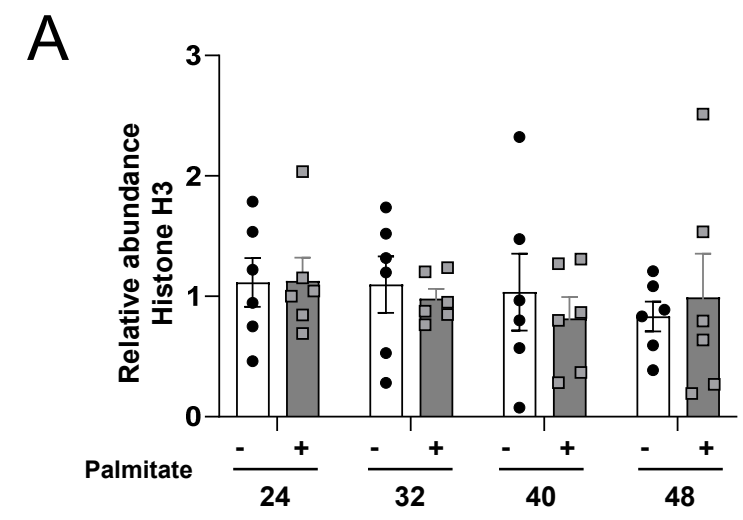

Time after synchronization $(\mathrm{h})$

C

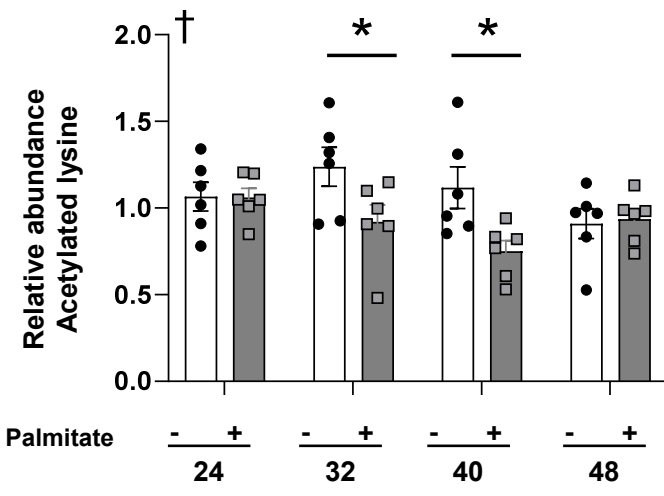

Time after synchronization (h)
B

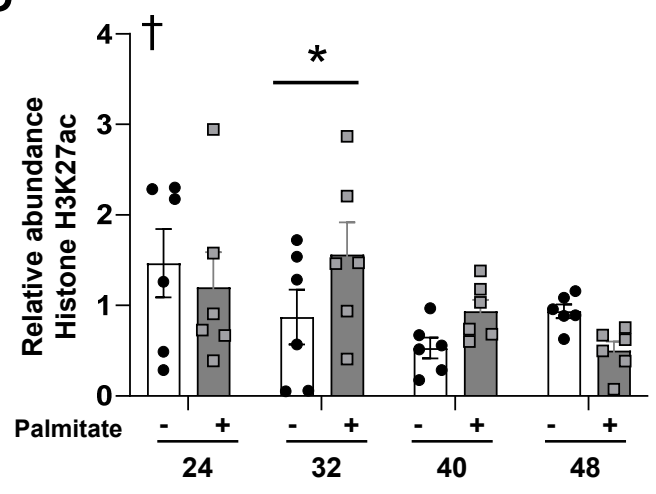

Time after synchronization (h)

D

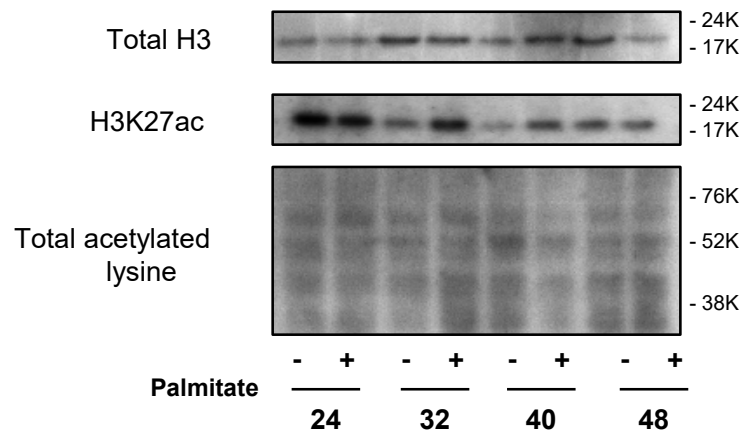

Time after synchronization (h) 
bioRxiv preprint doi: https://doi.org/10.1101/2021.02.23.432336; this version posted February 23, 2021. The copyright holder for this preprint (which was not certified by peer review) is the author/funder, who has granted bioRxiv a license to display the preprint in perpetuity. It is made available under aCC-BY-NC-ND 4.0 International license.

\section{Figure 5}

A

Palmitate treatment
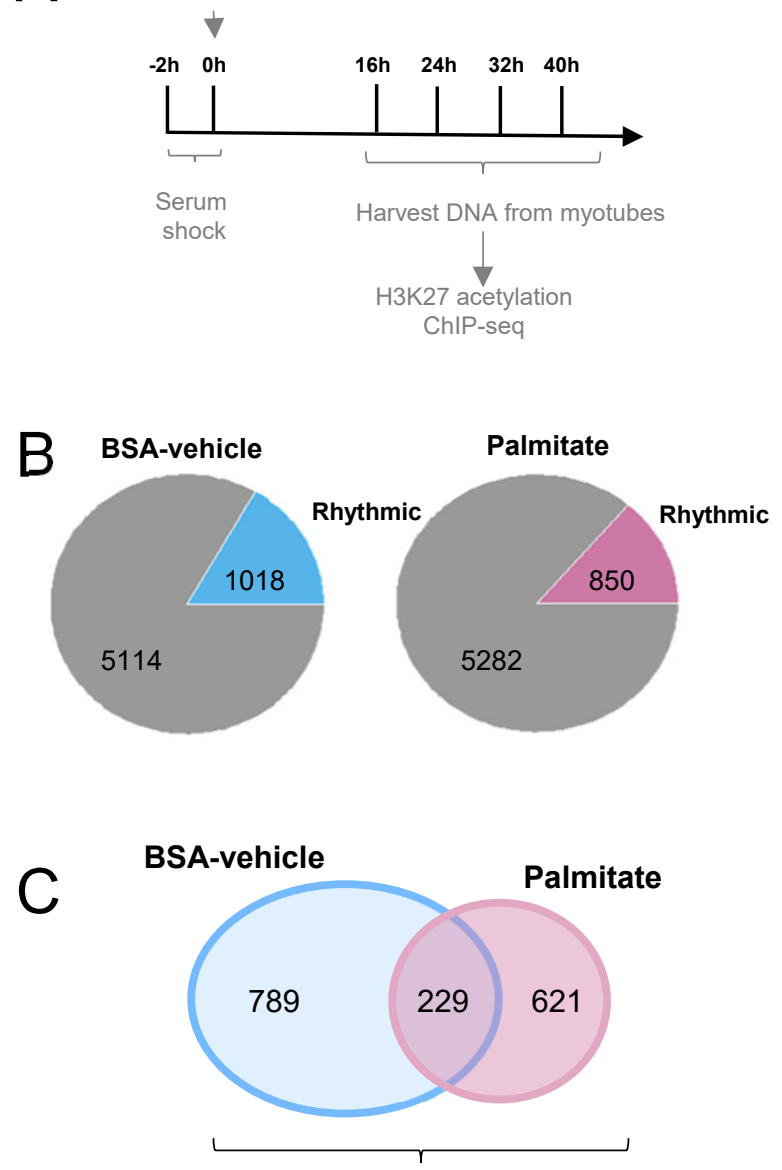

All cycling regions
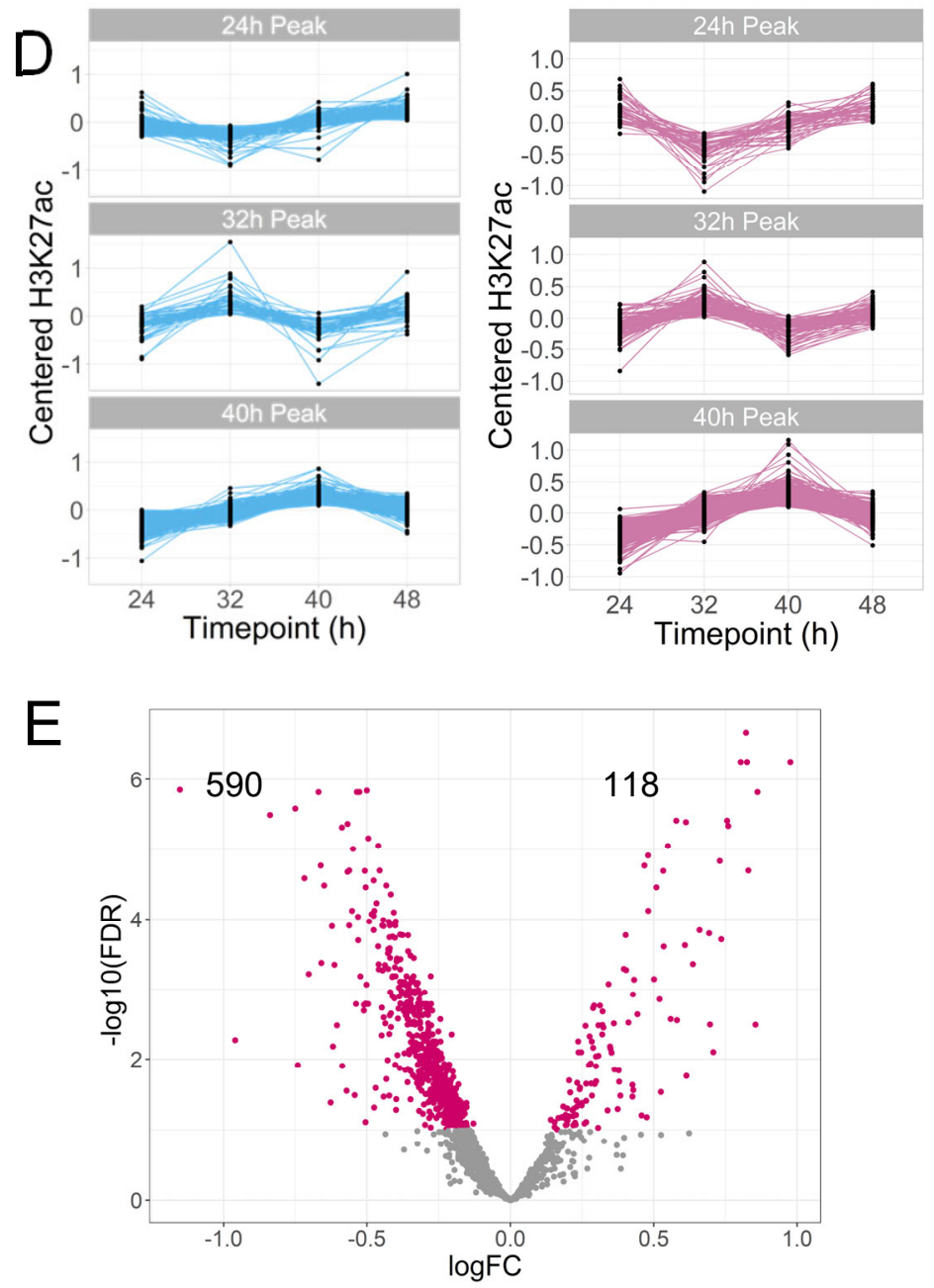
bioRxiv preprint doi: https://doi.org/10.1101/2021.02.23.432336; this version posted February 23, 2021. The copyright holder for this preprint (which was not certified by peer review) is the author/funder, who has granted bioRxiv a license to display the preprint in perpetuity. It is made available under aCC-BY-NC-ND 4.0 International license.

\section{Figure 6}

A

BSA-vehicle

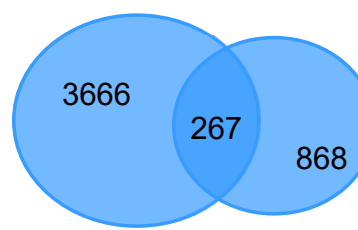

RNA-seq H3K27ac

$\checkmark$

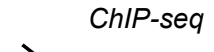

\section{Palmitate}

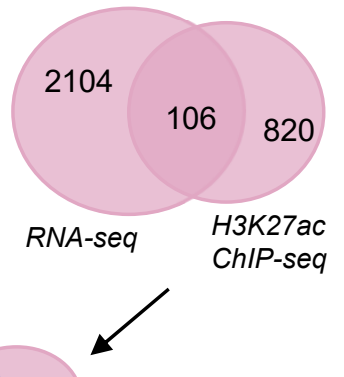

$\begin{array}{lll}252 & 15 & 91\end{array}$

B

$4000300020001000 \quad 0$

Rhythmic Genes

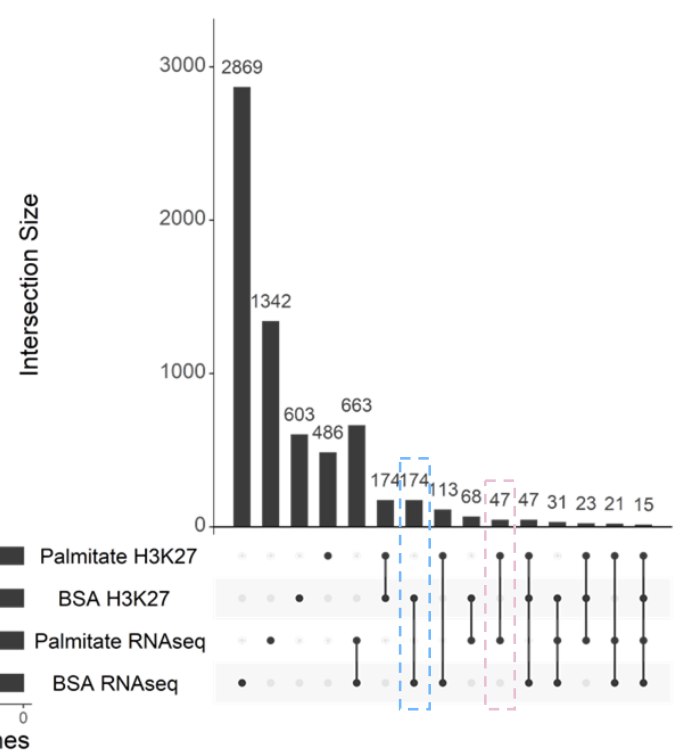


bioRxiv preprint doi: https://doi.org/10.1101/2021.02.23.432336; this version posted February 23, 2021. The copyright holder for this preprint (which was not certified by peer review) is the author/funder, who has granted bioRxiv a license to display the preprint in perpetuity. It is made available under aCC-BY-NC-ND 4.0 International license.

\section{Figure 7}
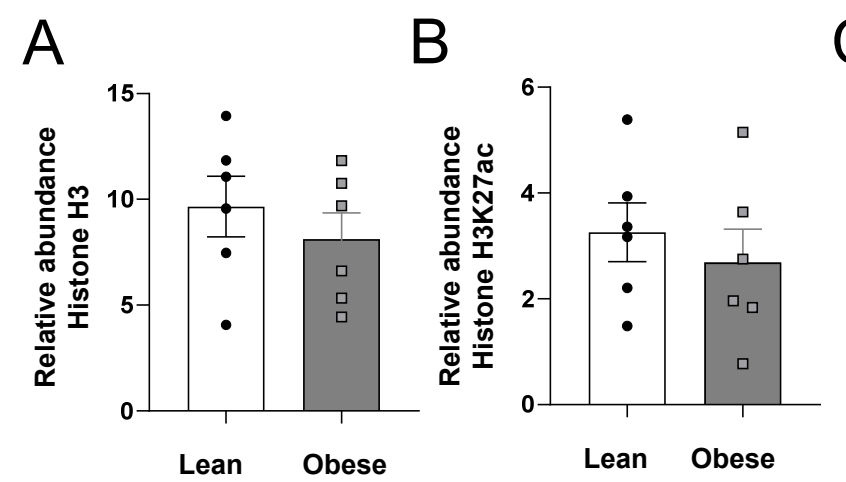

Total H3

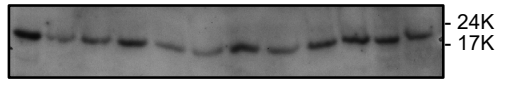

H3K27ac

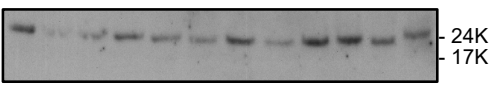

L O L O L O L O L OLO
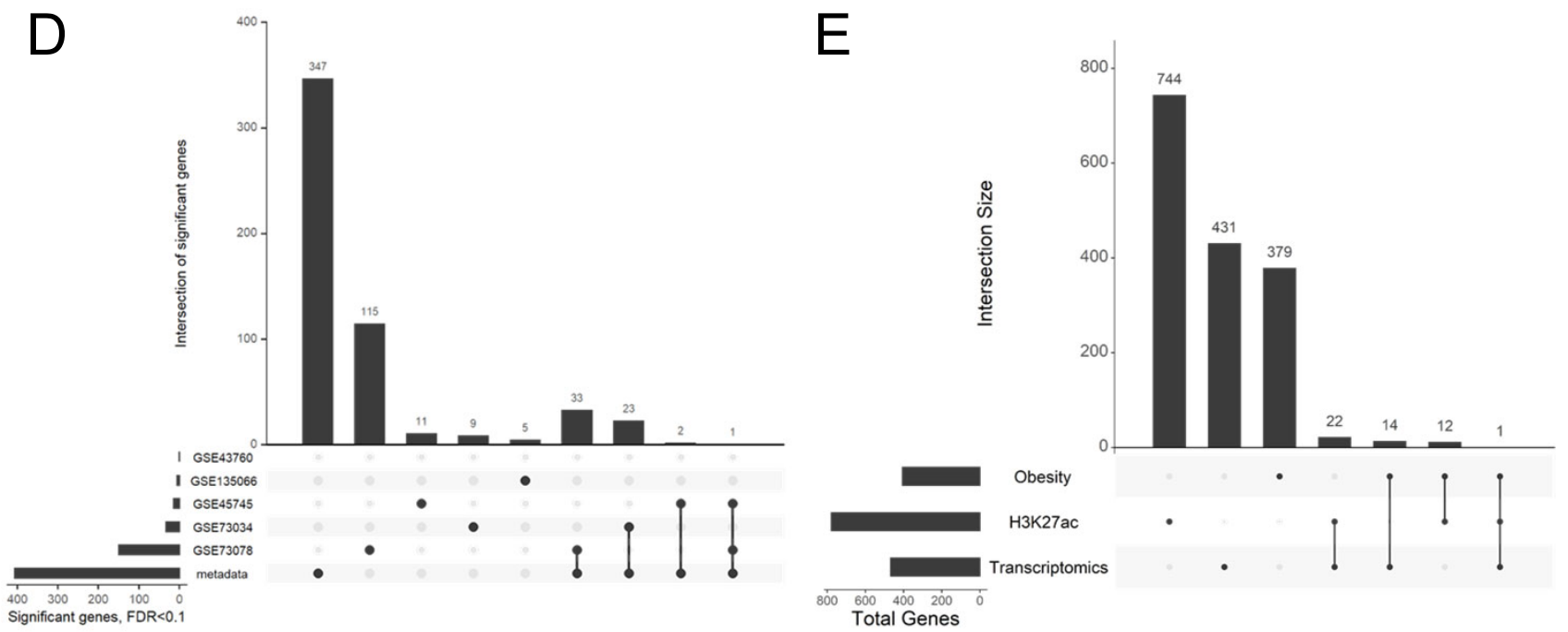
Table 1. Clinical Characteristics of the Study Participants.

\begin{tabular}{lcc}
\hline & $\begin{array}{c}\text { Normal weight } \\
\text { Men (n=6) }\end{array}$ & Oen (n=6) \\
\hline Age $(\mathrm{yr})$ & $53 \pm 3$ & $48 \pm 2$ \\
Body weight $(\mathrm{kg})$ & $79.8 \pm 2.6$ & $103.3 \pm 1.6^{*}$ \\
BMI $\left(\mathrm{kg} / \mathrm{m}^{2}\right)$ & $24.2 \pm 0.3$ & $31.1 \pm 0.7^{*}$ \\
fP-Glucose $(\mathrm{mmol} / \mathrm{L})$ & $5.4 \pm 0.2$ & $6.5 \pm 0.3$ \\
fP-Insulin $(\mathrm{pmol} / \mathrm{L})$ & $39.1 \pm 7.2$ & $116.3 \pm 26.8^{*}$ \\
HOMA-IR & $1.3 \pm 0.2$ & $4.3 \pm 1.2^{*}$ \\
fP-Cholesterol $(\mathrm{mmol} / \mathrm{L})$ & & $5.2 \pm 0.5$ \\
$\quad$ Total & $4.9 \pm 0.2$ & $2.9 \pm 0.5$ \\
$\quad$ LDL & $3.3 \pm 0.2$ & $1.6 \pm 0.3$ \\
$\quad$ HDL & $1.3 \pm 0.05$ & $1.8 \pm 0.3^{*}$ \\
fP-Triglycerides $(\mathrm{mmol} / \mathrm{L})$ & $0.9 \pm 0.1$ & \\
\hline
\end{tabular}

Results are mean \pm SEM for normal weight men and men with obesity. Differences between normal weight and men with obesity were determined using unpaired Student's $t$-test. ${ }^{*} \mathrm{P}<0.05$ versus normal weight. 
Table 2. Transcriptomic Studies Included in the Meta-Analysis.

\begin{tabular}{|c|c|c|c|c|c|c|c|c|}
\hline GEO & Biopsy & $\operatorname{Sex}$ & $\begin{array}{l}\text { Participants } \\
\text { (n) }\end{array}$ & $\begin{array}{c}\text { Age } \\
\text { (mean) }\end{array}$ & $\begin{array}{c}\text { BMI } \\
\text { (mean) }\end{array}$ & $\begin{array}{l}\text { Diagnosis } \\
\text { Group }\end{array}$ & PMID & Platform \\
\hline GSE43760 & Vastus Lateralis & $\mathrm{F}$ & 6 & 49 & 22.8 & Control & 27414688 & Affymetrix Human Gene 1.0 ST Array \\
\hline GSE43760 & Vastus Lateralis & $\mathrm{F}$ & 6 & 52 & 34.5 & MetS & 27414688 & Affymetrix Human Gene 1.0 ST Array \\
\hline GSE45745 & Vastus Lateralis & $\mathrm{F}$ & 6 & 30 & 23.3 & Control & 23583180 & Affymetrix Human Genome U219 Array \\
\hline GSE45745 & Vastus Lateralis & $\mathrm{F}$ & 5 & 46 & 41.9 & IR & 23583180 & Affymetrix Human Genome U219 Array \\
\hline GSE73034 & Vastus Lateralis & $\mathrm{U}$ & 7 & 55 & 21.9 & Control & 28725461 & Agilent-014850 Whole Human Genome Microarray 4x44K \\
\hline GSE73034 & Vastus Lateralis & $\mathrm{U}$ & 7 & 56 & 34.1 & MetS & 28725461 & Agilent-014850 Whole Human Genome Microarray 4x44K \\
\hline GSE73034 & Vastus Lateralis & $\mathrm{U}$ & 7 & 61 & 30.2 & $\mathrm{~T} 2 \mathrm{D}$ & 28725461 & Agilent-014850 Whole Human Genome Microarray 4x44K \\
\hline GSE73078 & Vastus Lateralis & $\mathrm{U}$ & 10 & 29 & 23.4 & Control & 27437034 & Agilent-039494 SurePrint G3 Human GE v2 8x60K Microarray 039381 \\
\hline GSE73078 & Vastus Lateralis & $\mathrm{U}$ & 10 & 40 & 32.9 & MetS & 27437034 & Agilent-039494 SurePrint G3 Human GE v2 8x60K Microarray 039381 \\
\hline GSE135066 & Vastus Lateralis & $\mathrm{U}$ & 14 & 40 & 24.5 & Control & 31519890 & Agilent-079407 ArrayXS Human V3 079025 \\
\hline GSE135066 & Vastus Lateralis & $\mathrm{U}$ & 49 & 40 & 51.4 & MetS & 31519890 & Agilent-079407 ArrayXS Human V3 079025 \\
\hline
\end{tabular}

Publicly available transcriptomic studies of skeletal muscle obtained from individuals with obesity and healthy volunteers (control) were collected from the GEO repository. Diagnosis group was based on different clinical measures to assess insulin sensitivity as reported in the published papers. Subjects were classified as insulin sensitive (control), insulin resistant with features of the metabolic syndrome (MetS), insulin resistant based on HOMA-IR (IR), or type 2 diabetic (T2D). Datasets included studies in female individuals (F) or mixed male and female participants (U, undetermined). The number of participants and the average mean and body mass index (BMI) for each study group is reported. 